\title{
Libera Pisano \\ Anarchic Scepticism: Language, Mysticism and Revolution in Gustav Landauer
}

Even for the anarchist, language is the rope of the law bound around his neck; even the most free philosopher thinks with the words of philosophical language. ${ }^{1}$

Gustav Landauer (1870 - 1919), a German-Jewish anarchist and a radical thinker, was brutally murdered by the Freikorps in Munich. He was an almost forgotten figure for a long time, even though his ideas exerted a crucial influence on the development of twentieth century Jewish thought and philosophy, particularly regarding the rehabilitation of utopian, messianic, anarchical and mystical elements. Landauer was one of very few Jewish authors permitting the word 'scepticism' to be included in the title of one of his works-namely Skepsis und Mystik ${ }^{2}-$ in my view this very term is the fil rouge running through all his political and philosophical thought. However, this feature has not received the proper attention by scholars, which focus mainly on Landauer's singular account of anarchism and mysticism, alongside his conception of revolution and community.

In this essay, I will attempt to shed light on the connection between Fritz Mauthner's (1849-1923) linguistic critique and Landauer's anarchy, showing the political implications of sceptical thought. To this end, I will focus on the sceptical features of Landauer's anarchist socialism by analysing the connection between scepticism and mysticism, the role played by scepticism in his thought of community and in his account of revolution, history and time, and the definition of his anti-political attitude as sceptical Lebensform.

\section{Anarchy as (Anti)political Epoché}

There is an affinity between anarchism and scepticism, even if this binomial has not yet received proper attention. One can define anarchism as an (anti)political attitude whose main features are a radical critique towards authorities and a challenge to the system of representations, while scepticism could be broadly defined as a method as well as an attitude, which criticizes dogmatic assumptions and leads to a suspension of judgment. If anarchism could be interpreted as a rejection of political representation, it is possible to extend these particular critiques to any general forms of label-

1 Cf. Fritz Mauthner, Beiträge zu einer Kritik der Sprache, 2nd edition, vol. 1 (Stuttgart and Berlin: J.G. Cotta'sche Buchhandlung, 1913), 221: 'Die Sprache legt auch dem Anarchisten den Strick des Gesetzes um den Hals und auch der freieste Philosoph denkt mit den Worten der philosophischen Sprache.' 2 Gustav Landauer, Skepsis und Mystik. Versuche im Anschluss an Mauthners Sprachkritik, in idem, Ausgewählte Schriften, vol. 7, ed. Siegbert Wolf (Lich/Hessen: Edition AV, 2011).

Ә OpenAccess. (c) 2018 Libera Pisano, published by De Gruyter. (cc) BY-NC-ND This work is licensed under the Creative Commons Attribution-NonCommercial-NoDerivatives 4.0 License. 
ling representation or to any dogmatic systems of rule. ${ }^{3}$ Anarchy and scepticism share this ongoing criticism the aim of which is not a concrete systematisation transforming them into their contraries with anarchy becoming an institutional framework and scepticism turning into dogmatism. Indeed, the transformation of these terms into their contraries is, in both cases, a slippery slope. Is it possible to define a thinker, in the midst of an ongoing criticism not accepting any assumption, as being a dogmatic sceptic? Conversely, are we to define an anarchist, embedded in his criticism towards the state and the system, as representative of another form of authority and power? These open questions may help us to shed light on the special and controversial affinities between scepticism and anarchy.

As is well known, the etymology of 'anarchy' is 'absence of government' or 'of leader' (archos), but at the same time it is a lack of 'arche', which is one of the key words of Greek ancient philosophy. 'Arche' has a double meaning: on the one hand, it means 'origin', 'beginning' and 'principle of action', on the other, 'power', 'command', 'authorities'. If the word 'arche' connects a temporal dimension to the authority, one can say that an anarchic thought par excellence has to take into account time and power, as Landauer did. Anarchy is not just an overthrowing of the 'arche', but starts with a process of doubting and calling into question the status quo. As anarchy denies all forms of systematisation, it is a kind of suspension of authority, which, in my view, seems to be a form of (anti)political epoché.

\section{Gustav Landauer at the Crossroad of Several Paths}

As a political activist and writer, journalist and translator, Landauer was one of the most important thinkers combining Jewish messianism with anarchy, politics with mysticism, and a romantic philosophy of history with a belief in the urgency of change. His works comprises many articles, translations, fragments, reviews, and a number of discourses; important milestones are Die Revolution and Aufruf zum Sozialismus, but his only complete philosophical study, on which he worked for two years following his release from prison early in 1900, is Skepsis und Mystik.

The complicated intrigue of Landauer's anarchy concerns the conjunction of two levels: the mystical experience and the political action. The weave of these elements positions his thought at a crossroads of several paths, something quite unique in the history of philosophy. At least three reasons demonstrate how he is to be considered a complex thinker: firstly, his works are unsystematic; secondly, he mixes up different and-apparently-opposite elements; and thirdly he gives a singular definition to some key concepts. Scholars have used many adjectives in attempting to define his political socialist anarchism: mystical, anarchical, regressive, Gemeindesozialismus

3 See Jesse S. Cohn, Anarchism and the Crisis of Representation: Hermeneutics, Aesthetics, Politics (Selinsgrove: Susquehanna University Press, 2006). 
to name but a few. His particular idea of socialism is based on an anarchic opposition toward any form of authority including political, social, ethical, and religious articulation of power. It is at the same time a project of liberation from all the forms of enslavement, interior and external, and a showing of the path required to take one from isolation to community-from theory to praxis.

At this point, I feel it pertinent to consider Landauer's biography. Born, $7^{\text {th }}$ April, 1870, to a secular Jewish family in Karlsruhe, southern Germany, he studied German and English literature, philosophy and art history in Heidelberg, Strasbourg and Berlin. However, he completed none of these studies as his political militancy had him banned from all German universities. Stirner, Nietzsche, Ibsen, Spinoza and Schopenhauer are just a few of the many philosophers he was impressed by in that time. His first political commitments saw him rise to the top of German anarchist circles during the 1890s. ${ }^{4}$ This political activity and anarchist commitment, led to his acquaintance with prominent activists such as Peter Kropotkin, Max Nettlau, and Errico Malatesta. ${ }^{5}$ His biographer Ruth Link-Salinger tells us this period was devoted 'to a systematic definition of what anarchism was to be and was not to be, ${ }^{6}$ and this was arrived at also due to his collaboration with Fritz Mauthner.

In the first decade of 1900, Landauer withdrew almost entirely from public activity to engage in private study. He was to favour a more inner, philosophical and mystical idea of anarchism to the political manifestations of the time. This introspection was spurred by his translation of Meister Eckhart in prison and a deep affinity with the Mauthner's Sprachskepsis. ${ }^{7}$ This new vein of Landauer's thought is sourced his "Durch Absonderung zur Gemeinschaft," a speech given at a meeting of the newly founded circle Neue Gemeinschaft-where he met Martin Buber and Erich Mühsam -and later was to serve as the first chapter of his Skepsis und Mystik. During these years Landauer and his second wife (the poet and translator, Hedwig Lachmann, whom he married in 1903) were extremely active translating Peter Kropotkin, Oscar Wilde, Walt Whitman, and Rabindranath Tagore.

\footnotetext{
4 In the 1893 he participated in the Zurich congress of the second International as an anarchist delegate. The congress, dominated by German social democrats, expelled him along with the other anarchists. August Bebel-the leader of the social democrats-accused him of being a police informer. When Landauer returned to Berlin, he spent almost one year in prison for the writings he published in Der Sozialist. For Landauer's life, cf. Charles B. Maurer, Call to Revolution: The Mystical Anarchism of Gustav Landauer (Detroit: Wayne State University Press, 1971); Eugene Lunn, Prophet of Community: The Romantic Socialism of Gustav Landauer (Berkeley: University of California Press, 1973); Ruth LinkSalinger, Gustav Landauer: Philosopher of Utopia (Indianapolis: Hackett Publishing Co., 1977): 74-76. 5 He travelled as a anarchist delegate to a second international congress in London where the anarchists were-once more-excluded and organised for themselves another conference. Landauer prepared a report for the occasion From Zurich to London, which became his most translated piece at that time.

6 Link-Salinger, Gustav Landauer: Philosopher of Utopia, 48.

7 Between 1893 and 1900 he spent a total of 18 months in prison on various charges of libel and defamation.
} 
In 1906, Buber became editor in chief of a book series called Die Gesellschaft and asked his friend Landauer to write a book on the intriguing topic of revolution. Landauer's essay was published in 1907 and this year marked his return to political activism; in fact, he published "30 Socialist theses" ism, of 1911, which represents the peak of his political contribution. In May 1908, Landauer initiated the Sozialistischer Bund whose goal was to form small, independent communities or settlements as a material foundation for a new form of society and an embodiment of his notion of socialism. With the outbreak of war, Landauer and Hedwig Lachmann were isolated, being among the few pacifistic voices in Germany at that time. The majority of anarchists and leftist thinkers welcomed the war as an opportunity of political renovation. ${ }^{9}$ Landauer was convinced the war was nothing but the extreme outcome of nationalism and imperialism. In 1917 he and his wife decided to move to Krumbach, southern Germany. In 1918 Hedwig died of pneumonia and his enormous loss has been interpreted by many biographers and friends as a point of no return in Landauer's life and justification for his 'sacrifice' or 'martyrdom' to the Munich Soviet Republic; in fact, in November 1918 he joined the Bavarian Revolution as one of its intellectual leaders. He was brutally murdered by the Freikorps (Free corps) on the $2^{\text {nd }}$ of May in 1919.

Landauer's milieu was fin-de-siècle and pre-World War I. His generation, born in the nineteenth century living up to the outbreak of the war were faced with a great loss of structure and order and experienced great alienation that led many to a rejection of traditions. Two vital coordinates help understand Landauer's contribution: the Sprachkrise and the Neue Mystik. German Jews played a pivotal role in these particular German phenomena emerging at the beginning of the twentieth century. ${ }^{10}$

8 His essay entitled "Volk and Land: 30 Socialist theses"-published in Die Zukunft in January 1907focussed on the problem of the state and voluntary cooperation and was simultaneously a programme for new, concrete organisation.

9 See Ulrich Sieg, Jüdische Intellektuelle im Ersten Weltkrieg (Berlin: Akademie Verlag, 2008): 145150. Even Buber followed the general trend of German nationalism. In 1916, in the editorial "Die Losung" of the first issue of Der Jude, Buber took an ambiguous stand: on the one hand, he emphasised that Judaism had no connection with war, on the other he praised the individual commitment to the war as an effort to discovery community. Furthermore, in his essay "The spirit of the Orient and Judaism," Buber celebrated Germany for its spiritual affinity to the Eastern peoples and strong cultural interaction with Judaism, by defending the superiority of German spirit compared with other nations. Landauer was angry and disappointed by such arguments, rejecting the Kriegsbuber and his mere aestheticism and formalism. Community cannot be discovered in the midst of war and murder. Under Landauer's pressure, Buber later became hostile to the war. Landauer called his friend 'War Buber' in the letter of May 12, 1916. See Grete Schaeder, ed., Martin Buber. Briefwechsel aus sieben Jahrzehnten, vol. 1 (Heidelberg: Lambert Schneider, 1972), 433. This letter doesn't appear in the volume of Landauer's letter edited by Buber, Gustav Landauer, Sein Lebensgang in Briefen, 2 vols., ed. Martin Buber (Frankfurt am Main: Rütten \& Loening, 1929).

10 Cf. Rolf Kauffeldt, "Anarchie und Romantik," in Gustav Landauer im Gespräch. Symposium zum 125. Geburtstag, eds. Hanna Delf and Gert Mattenklott (Tübingen: Max Niemeyer, 1997): 45; Adam 
The so-called Sprachkrise was a complex critique of language discussed by poets and intellectuals in philosophical and literary debate during the years leading up to World War I (von Hofmannsthal, Schnitzler, Kraus, all the Jung-Wien members, etc.). ${ }^{11}$ Its authors were beginning to doubt the role of language from many perspectives; the gap between language and reality renders the former into a defective tool presenting an insurmountable obstacle of grasping reality and revealing the truth. Even to this day the phenomenon of Sprachkrise has not been sufficiently focussed on in philosophical research, as it has been interpreted as a literal and cultural movement and not subject matter appropriate to the discourse of philosophy. However, in my view, it marks a turning point in the history of contemporary philosophy, as this sceptical-linguistic attitude, focussed special attention among German Jewish thinkers on language, anticipating the so-called 'linguistic turn'. In this constellation Mauthner and Landauer were crucial, with the former (in the wake of this sceptical approach) building a bridge between philosophy and literature, and the latter donating a political connotation.

The second coordinate, the Neue Mystik, was a reinterpretation by poets and writers of mysticism in Germany at the turn of the twentieth century. ${ }^{12}$ This new kind of mysticism does not deal with the traditional idea of a mystical union between God and soul, but rather with a feeling of awareness of connection between individual and community, present and past. This kind of secularised mysticism combines aesthetic-linguistic aspects-it is no coincidence most involved were writers and poetssharing a political and social idea of the regeneration of humankind. ${ }^{13}$ Landauer plays an active role in many political attempts to rethink community on a social and mystical basis; ${ }^{14}$ furthermore, his brilliant translation of Meister Eckhart's works significantly contributed to this new conception of mysticism.

M. Weisberger, The Jewish Ethic and the Spirit of Socialism (New York and Frankfurt am Main et al.: Peter Lang, 1997): 163.

11 See Gert Mattenklott, “Gustav Landauer. Ein Portrait,” in Gustav Landauer Werkausgabe, eds. Gert Mattenklott and Hanna Delf, vol. 3 (Berlin: Akademie, 1997): XVII: 'Mauthner, Hugo von Hofmannsthal, Buber, Kraus oder Landauer die ihre Skepsis in ihrer Literatur oder-wie im Falle von Buber und Landauer-auch ihren Übersetzungen zugleich produktiv umzusetzen suchten-das Phänomen Sprachkrise zu beschreiben und erklären.'

12 For instance, Julius and Heinrich Hart, Wilhelm Bölsche, Willy Pastor, Rainer Maria Rilke, Alfred Mombert, Bruno Wille etc.

13 Cf. Walther Hoffmann, "Neue Mystik," in Die Religion in Geschichte und Gegenwart, eds. Friedrich Michael Schiele and Leopold Scharnack, vol. 1 (Tübingen: Mohr, 1913): 608-611; Uwe Spörl, Gottlose Mystik in der deutschen Literatur um die Jahrhundertwende (Paderborn: Schöningh, 1997); Martina Wagner-Egelhaaf, Mystik der Moderne. Die visionäre Ästhetik der deutschen Literatur im 20. Jahrhundert (Stuttgart: Metzler, 1989); Anna Wolkowicz, Mystiker der Revolution. Der utopische Diskurs um die Jahrhundertwende (Warsaw: WUW, 2007).

14 The connection between a new idea of community and a particular idea of language was also experienced at that time by the organisation Neue Gemeinschaft, formed by a group of artists and writers who shared the idea of the brothers Heinrich and Julius Hart known for their literary criticism. Their attempt was to offer a revitalisation of society in accordance with a reform of literature and 


\section{Linguistic Scepticism and Anarchist Thought: Mauthner and Landauer}

Fritz Mauthner and Gustav Landauer were bound by a deep, lifelong intellectual friendship, evidenced by a huge epistolary. ${ }^{15}$ The former's linguistic scepticism was used by Landauer as the tool for unmasking and smashing the oppressive idols hidden in language and its supposed truths. ${ }^{16}$ Mauthner's treatment of language as a deceptive tool for human knowledge is at the root of Landauer's thought of anarchy. He used a linguistic-sceptical strategy to dismantle the power of the state and lead to a community based on a new idea of justice. While Mauthner focussed attention on the metaphorical and illusory value of language and human knowledge mediated by words, Landauer implemented linguistic scepticism to develop another political model. ${ }^{17}$

Fritz Mauthner was a philosopher and sceptic of language; he is an almost forgotten figure, who, nevertheless, produced a huge body of work: three volumes of Contributions toward a Critique of Language, a Dictionary of Philosophy, History of

the spiritual guide was the metaphysical and religious idea of Julius Hart explained in his works as Der neue Gott and Die neue Welterkenntnis. However, this kind of mystical environment was incapable -according to Landauer who left the organisation one year later-to change society. Furthermore, during World War I, he was active in some anti-militaristic circles-e.g. Forte Kreis, Bund Neues Vaterland and Zentralstelle Völkerrechte-whose goals were to create an alternative community.

15 See Gustav Landauer and Fritz Mauthner, Briefwechsel 1890-1919, eds. Hanna Delf and Julius H. Schoeps (München: Beck, 1994).

16 On linguistic scepticism, cf. Christian Mittermüller, Sprachskepsis und Poetologie. Goethes Romane 'Die Wahlverwandschaften' und 'Wilhelm Meister Wanderjahre' (Tübingen: Niemeyer, 2008); Magdolna Orosz and Peter Plesner, "Sprache, Skepsis und Ich um 1900. Formen der belletristischen Ich-Dekonstruktion in der österreichischen und ungarischen Kultur der Jahrhundertwende," in '...und die Worte rollen von Ihren Fäden fort...': Sprache, Sprachlichkeit, Sprachproblem in der österreichischen und ungarischen Kultur und Literatur der Jahrhundertwende, eds. Magdolna Orosz, Amália Kerekes, and Katalin Teller (Budapest: ELTE, 2002): 355-368; Günter Saße, Sprache und Kritik: Untersuchung zur Sprachkritik der Moderne (Göttingen: Vandenhoeck \& Ruprecht, 1977); Martin Kurzreiter, Sprachkritik als Ideologiekritik bei Fritz Mauthner (Frankfurt am Main: Lang, 1993), 25-80; Gerald Hartung, Sprach-Kritik: Sprach- und Kulturtheoretische Reflexionen im deutsch-jüdischen Kontext (Weilerswist: Velbrück Wissenschaft, 2012).

17 The connection between anarchy and language stems from Proudhon who considered the question of language connected to the idea of collective being. See Pierre Joseph Proudhon, "An Anarchist's View of Democracy," trans. Robert Hoffmann and S. Valerie Hoffman, in Anarchism, ed. Robert Hoffman (New York: Atherton Press, 1970): 52: 'Where and when have you heard the People? With what mouths, in what language do they express themselves?' According to him, nature and language produce associations and divisions through an ongoing articulation. Language is, on the one hand, a dispositive of power, on the other, the milieu in which socialism could happen as language avoids private property. However, it is a tool for identifying representation and creating associations or boundaries, it is not by chance that institutional power passes through language. 
Atheism in the Western Society and numerous essays and novels. ${ }^{18}$ The three volumes Contributions toward a Critique of Language are an example of thoroughgoing linguistic scepticism in the history of philosophy, coordinating linguistic doubt with epistemology. Mauthner's Contributions were written in an attempt to demonstrate how language is redundant as a means for the perception of reality and, insofar as knowledge is mediated by words, impossible. His originality lies in his anticipation of the linguistic turn in arguing that the philosophy of language sheds critical light on all philosophical questions. ${ }^{19}$

Thanks to Mauthner's intercession, Landauer translated some of Meister Eckhart's mystical writings into modern German, and these were used as materials aids for the writing of Contributions toward a Critique of Language. The two friends' cooperation in linguistic critique was deeply relevant; in prison Landauer edited Mauthner's Contributions and after publication of the first volume reviewed it for $\mathrm{Zu}$ kunft. The ongoing discussion and confrontation between them led to a discussion on the limits of language and an exploration of the political effects of mysticism.

According to Mauthner, language deletes the uniqueness of our experience by transforming it into a series of tautologies and, although it can refer to reality only metaphorically, it is the only medium of human knowledge. Words exercise a social and political power; even if language is a collection of illusions, it is a dangerous weapon. All metaphysical abstractions are falsities, a mere trick of the language, which forces us to believe that each noun corresponds to a pre-existing substance. If the word is not representative of reality, the most important task of philosophy is the critique of language, i.e. the liberation from the superstitions and the tyranny of words (Wortfetischismus, Wortaberglauben, Worttyrannei).

Mauthner's logos-scepticism has many different features: a radicalisation of empiricism, the coincidence between thinking and speaking, the relevance of use and linguistic habits, the utopia of communication, the liberating task of philosophy, his controversial relationship with Judaism and silent mysticism. In my view, the practical aim of Mauthner's philosophy, i.e., the liberation from the superstitions of words is in accordance with the therapeutic value of ancient scepticism and, more-

18 Fritz Mauthner, Beiträge zu einer Kritik der Sprache; idem, Wörterbuch der Philosophie. Neue Beiträge zu einer Kritik der Sprache, 2nd edition, 3 vols. (Leipzig: Meiner, 1923); idem, Der Atheismus und seine Geschichte im Abendlande, 4 vols. (Stuttgart and Berlin: DVA, 1924).

19 On Mauthner's linguistic scepticism, see Luisa Bertolini, La maledizione della parola di Fritz Mauthner (Palermo: Supplementa, Aestetica, 2008); Gerald Hartung, ed., An den Grenzen der Sprachkritik: Fritz Mauthners Beiträge zur Sprache- und Kulturtheorie (Würzburg: Königshausen und Neumann, 2003); Joachim Kühn, Gescheiterte Sprachkritik: Fritz Mauthners Leben und Werk (Berlin and New York: De Gruyter, 1975); Elizabeth Bredeck, Metaphors of Knowledge: Language and Thought in Mauthner's Critique (Detroit: Wayne State University Press, 1992). 
over, his mystical silence, arising from his critique, is a modern achievement of ancient ataraxia. ${ }^{20}$

Landauer interpreted the curative value of Mauthner's linguistic scepticism in a political way. In both perspectives there is an attempt at liberation from the tyranny of language and the chains of authority; however, while Mauthner develops a radical criticism, which leads him to a dismantling of language and solitary and elitist path of silence and mysticism, Landauer goes a step further and connects this introspective tendency emanating from scepticism with a liberation from isolation to experience a true community. Mauthner's attack on language as mere word superstitions, and in particular his questioning of belief in the empirically isolated self, provided Landauer with a useful basis for defending his own mysticism. He combined Mauthner's linguistic scepticism with an anarchic critique of society, by admitting the affinity between Sprachkritik and his account of anarchism and socialism. ${ }^{21}$

\section{Active Scepticism and Social Mysticism}

Landauer's philosophical work, Skepsis und Mystik is based on Mauthner's critique of language. ${ }^{22}$ Its structure is puzzling, comprising of a collection of several essays, some of which appeared separately before the book. The first chapter, Das Individuum als Welt was initially a speech entitled Durch Absonderung zur Gemeinschaft, Landauer gave in 1901 for the Neue Gemeinschaft; the second chapter is made up of an article published $23^{\text {rd }}$ November 1901 in Zukunft and a review of Julius Hart's book Die neue Welterkenntnis written by Landauer in 1902; the third chapter-Die Sprache als Instrument-had not been published previously.

In this book he recognises linguistic scepticism as the foundation for new political action, for it being a radical critique of human illusions. Landauer compares mysticism and scepticism in terms of their common power of negation and destruction of egoism. ${ }^{23}$ According to him, scepticism exposes the world in all its nullity and is thus shows how the deepest scepticism engenders the highest mysticism. The act of doubting our knowledge, language, representations of the world and political in-

20 Cf. Libera Pisano, "Misunderstanding Metaphors: Linguistic Scepticism in Mauthner's Philosophy," in Yearbook of the Maimonides Centre for Advanced Studies 2016, eds. Giuseppe Veltri and Bill Rebiger (Berlin and Boston: De Gruyter, 2016): 95-122.

21 In a letter to Mauthner of May 17, 1911, Landauer wrote: 'Gewiss ist Sprachkritik untrennbar zu dem gehörig, was ich meinen Anarchismus und Sozialismus nenne.' Cf. Landauer, Sein Lebensgang in Briefen, vol. 1, 361.

22 Landauer, Skepsis und Mystik. Versuche im Anschluss an Mauthners Sprachkritik, in idem, Ausgewählte Schriften, vol. 7, ed. Siegbert Wolf (Lich/Hessen: Edition AV, 2011). See Maurer, Call to Revolution, 67: 'Skepsis und Mystik might be called Landauer's philosophic manifesto.'

23 See Landauer, Sein Lebensgang in Briefen, vol. 2, 245: 'Die echte, klassische Mystik hat ja übrigens mit solchen egoistischen Wünschen nicht nur nichts zu tun, sondern zerstört sie so gründlich wie irgendein Skeptizismus.' 
stitutions is not a mere theoretical exercise. Calling into question reality by doubting the power of language could lead to a new understanding and develop a new idea of community. ${ }^{24}$ Thenceforth, he uses linguistic scepticism as a political strategy for an antiauthoritarian critique and a complex mystical thinking of community, in which the individual is indissolubly bound to the entire past and present of humanity.

Scepticism is not only unmasks the cult of the state, the very task of doubting leads to a political renewal of mankind. According to Landauer, mystical introspection-deeply connected with scepticism-is a form of deep, individual connection to the world and the key to the passage from isolation to community. The real innovation of his political thought is the connection between a theoretical mysticism and a 'terrestrial'25 one. His singular account of mysticism does not deal with a separation from the world, but rather with a form of individual deep connection to the inner world and to the past.

In the introduction of Skepsis und Mystik, he underlined Eckhart's significance as the key to understanding his mystic anarchy. ${ }^{26}$ Landauer emphasised that his metaphysical approach combining Christian dogma and pantheism should become the model for a political interpretation of mysticism; Eckhart proposed an idea of connection between the single entity and the whole world by going beyond the limits of language. ${ }^{27}$ In fact, his thought-according to Landauer-was not only a contemplatio mundi, but was also rooted in an essential transformation of the relationship with the world: 'his mysticism is scepticism, but also vice versa. ${ }^{28}$ It is no coinci-

24 The first philosopher who emphasised this aspect was undoubtedly Friedrich Nietzsche, who had been well studied by Mauthner as well as Landauer. As Paul Goodman, Speaking and Language: Defense of Poetry (New York: Vintage Books, 1971), 26, wrote: 'One of the most powerful institutions is the conventional language itself. It is very close to the ideology and it shapes how people think, feel, and judge what is functional.' The attack on signification is a kind of attack on an order that shaped human beings.

25 Lunn, Prophet of community, 132.

26 Between 1893 and 1900 Landauer spent almost 18 months in prison. During his six-month imprisonment in Tegel he translated Eckhart and wrote a part of his Skepsis und Mystik.

27 Cf. Thorsten Hinz, Mystik und Anarchie. Meister Eckhart und seine Bedeutung im Denken Gustav Landauer (Berlin: Kramer, 2000); Christa Dericum, "Revolutionäre Geduld. Gustav Landauer," in Christentum und Anarchismus. Beiträge zu einem ungeklärten Verhältnis, ed. Jens Harms (Frankfurt am Main: Athenäum, 1988): 107: 'Der mittelalterliche Mystiker Meister Eckhart, dessen Werk Landauer während der Gefangenschaft ins Deutsche übersetzte, lehrte ihn, ganz zu sich zu kommen und bei sich zu verweilen.'

28 Gustav Landauer, "Vorwort," in Meister Eckhart, Meister Eckharts Mystische Schriften (Berlin: Schnabel, 1903): 7. It is worth mentioning Fritz Brupbacher's (1874-1945) note here. He stated that a mystic should also be a sceptic and emphasised the relevance of Landauer's work, especially how he articulated the relationship between language and authority. This note of Brupbacher is recorded by Franz W. Seiwert, Schriften. Der Schritt, der einmal getan wurde, wird nicht zurückgenommen, eds. Uli Bohnen and Dirk Backes (Berlin: Kramer, 1978), 36: "Wer nicht zu wissen glaubt, wohin der Mensch zu gehen habe, wer skeptisch ist, ob es überhaupt einen für alle gültigen Sinn des Lebens gäbe oder wer von diesem Sinn aussagt, dass er nur im Gewissen eines jeden Einzelnen liege und nicht intellektuell formulierbar sei, wer also Mystiker ist, der muss Anarchist sein. Auf diese 
dence that Landauer held the major exponents of scepticism in the history of philosophy to be mystics: from Dyonisius the Aeropagite to Boehme and Eckhart. Landauer offers a secularisation of mysticism by substituting 'God' with 'humanity', 'cosmos' with 'Volk' and by providing a new relation to the world. Community cannot be found initially in the external world but must be discovered in the interiority of the individual soul. Landauer sees in mysticism the way to overcome a violent account of anarchism and to think of a new form of community by crossing the atomisation of the individuals. ${ }^{29}$

\section{From Abstractions to Community: Spiritualisation of Social Bounds}

Landauer's controversial conception of mysticism, which leads to action, deals with his notion of Geist. Spirit is an ambiguous concept because it is both connection and independence, Verbindung and Unabhängigkeit. The binding power of spirit, synonymous of life, is an inner worldly feeling between man and man, man and earth, man and history that forges the real community; it is not an a priori principle, but rather its transcendence stems from men's action. This unity is not a form of dialec-

nahe Beziehung von Skepsis, Mystik und Anarchismus hat ja Landauer sehr klar hingewiesen. Es gibt gewiss viele Zwischenstufen zwischen Autoritäten und Anarchisten, Mischungen der Prinzipien; aber der Grundunterschied liegt eben darin, dass der Anarchismus die Besonderheit des Individuums in den Vordergrund rückt, während der Autoritär das Gemeinsame alle Individuen betont, die Notwendigkeit der Unterordnung des Besonderen unter das Gemeinsame. In der Sprache der mittelalterlichen Philosophie gesprochen: Der Autoritär ist Realist, der Anarchist Nominalist; der eine kennt ein aus den Produktionsverhältnissen zu bestimmendes allgemein gültiges Ziel, der andere erklärt alle solche allgemeinen Ziele für Schall und Rauch, das einmalige, irgendwohin wachsende Individuum ist ihm der Sinne des Lebens."

29 Thanks to the important works of Reiner Schürmann who reads Eckhart in an existential way, it is possible to define a form of mystic anarchy in Eckhart's thought, concerning two aspects in particular: the rethinking of time and the practical liberation from the concept of finality. In fact, in the Mystische Schriften translated by Landauer there is a redefinition of time, considered as an everlasting moment in which a spiritual union of the single and the whole takes place. This openness of time marks the divide because it leads to liberation from utilitarian dependence and seeking of God as a foundation. The second aspect deals with a transfiguration of all the relationships between man and man, man and world, man and God, which operates not as a final cause but as a suddenly irruption. These premises lead Eckhart to a rethinking of the abandonment and isolation from the outside word -Abgeschiedenheit-as the beginning of an ascetic exercise as an existential programme. In the Sermons the spiritual experience is not described as an ecstasy, but rather as a renewed and concrete form of a relationship with things and existence to forge reality and humankind. This practical Bildung is the revolutionary attempt of Eckhart mysticism to step back from causality, finality and spatiality. Cf. Reiner Schürmann, Maitre Eckhart et la joie errante (Paris: Rivages, 1972). On Landauer and Meister Eckhart, see the interesting contribution of Yossef Schwartz,"Gustav Landauer and Gershom Scholem: Anarchy and Utopia," in Gustav Landauer: Anarchist and Jew, eds. Paul Mendes-Flohr and Anya Mali (Berlin and Boston: De Gruyter, 2015): 172-190. 
tical recognition, but a social mysticism which is at the core of Landauer's political thought. The heart of his idea of anarchist socialism is the attempt to render authority superfluous and unnecessary through a new kind of relationship and cooperation between men. His idea of an organic community and an authentic bond between individuals was a complete rejection of modern atomisation and the state. In his For Socialism, Landauer defined spirit in the following way: 'spirit is communal spirit, spirit is union and freedom, spirit is an association of men, soon we will see it even more clearly, spirit is coming over men. ${ }^{30}$ If spirit arises from an association of man, isolation is an epiphenomenon of its absence. The main task of anarchy is to fill this separation's gap among the individuals.

A critique toward any individuality seen as abstraction is at the core of Landauer's thought. This could be paradoxical from an anarchic point of view, but his social mysticism is based on an acknowledgment of every single person seen as an indissoluble bond:

[I]t is time for the insight that there is no individual, but only unities and communities. It is not true that collective names designate only a sum of individuals: on the contrary, individuals are only manifestations and points of reference, electric sparks of something grand and whole. ${ }^{31}$

Landauer's emphasis on isolation is due to his personal experience and his interest in mysticism developed in prison..$^{32}$ Furthermore, according to him, the modern state is based on isolation and is an artificial surrogate for the spirit of the community. 'State' is nothing more than a word one uses in the attempt to project what is essentially an internal experience of dependence to a separate material construct; thence, state is a phantom and an idol. It is 'a social relationship; a certain way of people relating to one another. It can be destroyed by creating new social relationships; i.e., by people relating to one another differently. ${ }^{33}$ A violent overturning of the state is an illusion: 'those who believe that the state is also a thing or a fetish that can be overturned or smashed are sophists and believers in the Word. ${ }^{34}$

Landauer's theory of power is sophisticated in that he combines liberation from authority with the word's capacity of hypostasise abstractions taken from Mauthner's linguistic scepticism. The word's superstition-Wortaberglauben-is the ground for Landauer's fetishist conception of state. In both perspectives there is an attempt of

30 Gustav Landauer, For Socialism, trans. David J. Parent (St. Louis: Telos, 1968), 30.

31 This passage taken by Skepsis und Mystik is translated by Maurer; see Maurer, Call to Revolution, 71.

32 See ibidem, 10-11: 'For most of his life Landauer lived and worked in isolation from the main political currents of his time; but his efforts were, nonetheless, rooted in a tradition of social philosophy established and perpetuated by some of the most original personalities of the eighteenth and nineteenth centuries.' See ibidem, 48: 'Gustav Landauer began this century in prison.'

33 Gustav Landauer, “Weak Statesman, weaker people," in idem, Revolution and Other Writings: A political Reader, ed. and trans. Gabriel Kuhn (Oakland: PM Press, 2010): 214.

34 Ibidem. 
liberation from the tyranny of language and from the chains of authority. The famous sentence of Nietzsche-namely, 'Where the state ends, only there begins the human being who is not superfluous ${ }^{35}$-is used by Landauer to perform the anarchic tension against state, which is an artificial bond, a false illusion and an absence of spirit. State is an irrational fetish which produces social inequality through hierarchy and domination, but on the other hand his power depends on the community of human subjects.

The switch from a conception of state seen as an abstraction or a fetish into an idea of state seen as a condition is one of the most original aspects of Landauer's political thought. This idea is deeply revolutionary, for it does not deal with a violent destruction of the state, but rather with new behaviour and a new relationship. The way to sabotage the state is by means of the institution of authentic bonds among people instead of the crystallisation of relationships.

Landauer's idea of power was deeply influenced by Etienne de la Boétie and his Discourse on voluntary servitude, quoted in the Revolution. ${ }^{36}$ According to la Boétie, the tyrant's power is granted by the subjugated individuals who only need to refuse their support to overturn his power. Furthermore, it is worth noting that the de-transcendentalisation of the state in condition and relations anticipates Foucault's analysis of disseminated power and the following bio-political reflections of the twentieth century. ${ }^{37}$

Landauer's sceptical philosophy is not only a theoretical exercise, but is the foundation and the strategy for a particular idea of anarchy as Gemeinschaftsleben. At the outset of Skepsis und Mystik Landauer contends that scepticism has no value at all if it does not prepare the way for a newly created mysticism. Therefore, its function is to clear the ground for a new mysticism bound with a call to action. This kind of contradictio in adjecto of activism and mysticism is just one of the theoretical tensions in Landauer's thought. How could mysticism and scepticism-which generally lead to apraxia-be combined with a political action? How could a thought of community stem from a mystical attitude which is deeply elitist and individual?

35 Friedrich Nietzsche, Thus Spoke Zarathustra, eds. Adrian Del Caro and Robert Pippin (Cambridge: Cambridge University Press, 2006), 36.

36 In Die Revolution, Landauer-quoting La Boétie-admits: 'Where does the tremendous power of the tyrant derive from? It does not come from external power [...] no, its power comes from the voluntary servitude of men [...] It became a habit to be complacent in servitude; and habit is stronger than nature [...] tyranny is not a fire that has to be or can be extinguished. It is not an external evil. It is an internal flaw.' This message from La Boétie is at the core of Landauer's anarchy: 'human should not be united by domination, but as brother without domination: an-archy.' But he adds 'with spirit,' spirit that 'has to come over us.' At the end of the Revolution, Landauer compares La Boétie's notion of 'le contr'un' with his notion of 'le contr'etat': if the former is a group of individuals which recognise its servitude and rise above it, the second one is 'a community of people outside the state.' Cf. Landauer, Revolution, 151-173.

37 On this affinity, see Jesse S. Cohn, Anarchism and the Crisis of Representation, 69. 
Landauer's answer is the spiritualisation of social relations as a synthesis between mysticism and socialism. The creation of a real community passes through an individual mystical experience which results in dismissing the illusion and false bonds. The regeneration of humankind is in no way a naïve and palingenetic exhortation, but presupposes a kind of a personal conversion. The way one must sabotage the state is via the creation of authentic bonds among people; however, the creation of this bond stems from an individual awareness and withdrawal that leads to a deeper and more authentic connection with the world and the past. Through these paths the spirit opens up and discloses the revolution as a cathartic renewal of humankind.

A personal katabasis and a symbolic suicide are needed as a face to face with a weird negativity and a self-liberation:

So as not to be an isolate, lonely and God-forsaken, I recognise the world and sacrifice my ego to it, but only so that I might feel myself to be the world to which I have opened myself. Just as a suicide hurls himself into the water, so I crash precipitously into the world, but I find not death, rather life there. The ego kills itself so that the world ego might live. ${ }^{38}$

The social bounds are 'the bridges of light'39 that connect people. Revolution should lead to a community working as a reparation-that we can call tiqqun as restoration in the Lurianic sense ${ }^{40}$ of the fragments: 'because the world has fragmented into pieces and is divided and different from itself, we must flee into mystical seclusion to become one with the world. ${ }^{41}$

\section{Anarchic Time and the Sceptical Account of Revolution}

In my view, it is possible to see in Landauer's work a triple idea of time connected deeply to his anarchy: the first is the mystical transformation of space in time arising from scepticism and as a premise for renewal of the community in Skepsis und Mystik; the second is his articulation of time in the Revolution, where history is an open process of becoming which resists any attempt of dogmatisation; the third is his idea of revolution-inspired by the Jewish Jubilee-as an exercise of interruption of the present power relations in For Socialism.

38 Landauer, Skepsis und Mystik, 48. This passage was translated into English by Weisberger, The Jewish Ethic and the Spirit of Socialism, 168.

39 Landauer, Revolution, 118.

40 On the Lurianic notion of tiqqun in contemporary Jewish thought, see Lawrence Fine, "Tikkun: A Lurianic Motif in Contemporary Jewish Thought," in From Ancient Israel to Modern Judaism: Essays in Honor of Marvin Fox, vol. 4, eds. Jacob Neusner, Ernest S. Frerichs, and Nahum M. Sarna (Atlanta: Scholars Press, 1989): 35-53.

41 Landauer, Skepsis und Mystik, 18. This passage was translated into English by Weisberger, The Jewish Ethic and the Spirit of Socialism, 166. 
The relevance of the concept of time and the connection of the individual with his past are two important features of Landauer's thought. His idea of the regeneration of community-mainly in his Skepsis und Mystik-passes through an overcoming of the spatial and sensorial dimension to conceive a form of community based on a temporal dimension. In fact, according to Landauer, the spirit is not a spatial concept. ${ }^{42}$ In terms of the connection between time and politics, one can argue that Landauer interpreted the external world as a mere sign of the internal one. Spatial development is nothing but a moment in the flow of time: 'space must be transformed into time. ${ }^{43}$ In this task there is the need to find new metaphors, or new language, for an authentic community. His account of time stems from a kind of mystical vision: 'Time is not merely perceptual, but it is the form of our experience of self; therefore it is real for us, for the conception of the world that we must form from out of ourselves. ${ }^{44}$ The effort of keeping together a social and an individual level is based on a new conception of time in which there is a perpetual bond between past, present and future generations. ${ }^{45}$

In Skepsis und Mystik he argued that time and historical change were actually rooted in internal experience, while in Die Revolution he developed what we should call a sceptical idea of history. Die Revolution, written in 1907 and republished posthumously in 1919, is a unique and sophisticated essay which embodies the spirit of the time and contains an attempt at a sceptical-anarchistic philosophy of history. This book, however, is not an easy read; mainly for Landauer's ambiguous usage of the word 'revolution', which has at least three meanings in the text: firstly, revolution is a permanent movement connected to his philosophy of history where it is to be interpreted as the threshold between topia and utopia; secondly, a long historical period that begun with the modern era and is the sum of different and partial revolutions or transformations; ${ }^{46}$ thirdly, revolution is a realisation of the spirit which leads to the regeneration of the humankind and to the real community beyond state.

42 Gustav Landauer, "Die vereinigte Republiken Deutschlands und Ihre Verfassung, 25. November 1918," in Gustav Landauer und die Revolutionszeit 1918/1919, ed. Ulrich Linse (Berlin: Kramer, 1974): 63: 'Der Geist, meine Herren, ist keine Lokalitat, wo es am Platz ist, sich vorzudrängen; eher ist er so etwas wie magisch erfüllte Zeit.'

43 Landauer, Skepsis und Mystik, 87.

44 Ibidem, 85.

45 According to him heredity is a force and a continuum which shapes ancestral life into a new form. This idea is also taken by the third volume of Mauthner's Sprachkritik, where there is a definition of heredity as a redefinition of Platonic eternal form. Cf. Mauthner, Beiträge, vol. 3, 71.

46 In these pages of Die Revolution, Landauer developed a philosophy of history from Middle Ages to his day. Landauer sees Middle Ages as completely different from the modern principle of centralism and state power; while the millennium from 500 to 1500 was marked by ordered multiplicity, and the era from 1500 until now by a lack of spirit, individualisation, state, violence and so on, he adds: 'This is the complexity in which we find ourselves, this is our transition, our disorientation, our searchour revolution' (135). The development of individualism during the Renaissance undermined the Geist which was completely defeated by the reformation and Luther's doctrine of salvation. The great individualism and the atomization of the masses arrived with Luther, according to Landauer: 'He rad- 
Landauer's Revolution begins by calling into doubt any dogmatic and scientific conception of history. Doubting contains a political value and is a prelude to a new beginning connected to the formation of a new man and a new society; the rhythm of doubting is part of Landauer's philosophical style. He commenced his essay by admitting that history is not a science that requires scientific laws, because 'our historical data consist of events and actions, of suffering and relationships. ${ }^{47}$ At the outset of the book, Landauer adopted sceptical strategy to show the impossibility of a scientific definition of revolution; in fact, every scientific attempt cannot satisfy its understanding as a phenomenon. This is deeply connected to his idea of history as not fixed and unchanging, but in fact a sum of forces whose influence is permanent in our lives. In fact, whereas science creates theory and abstraction, history creates 'forces of praxis' in a process of Vergegenwärtigung, of becoming or of turning something into presence. However, Landauer tried to give a theoretical account of revolution connected to his conception of history, without any dogmatic presumption.

The entirety of history, according to him, is a sequence of topias-periods of order and fixed institutions-and utopias, which is moved by a desire for change, and 'consists of two elements: the reaction against the environment from which it emerges, and the memory of all known earlier utopias. ${ }^{48}$ He rejects a progressive idea of history. In fact, the past is not something finished, but always a process of becoming. History is not something already defined, everything is a result as well as a promise: 'there is only way for us, there is only future. The past itself is future. It is never finished, it always becomes. It changes and modifies as we move ahead. ${ }^{49}$ This historical becoming is both a passage from different phases as well as a permanent changing of the past at every stage of history. There is somehow a futurability of the past, and revolution is the period between of the old topia and the coming of the new one..$^{50}$

According to Landauer, revolution is not the telos-ultimate aim-of the history, but a meta-historical threshold, which needs a systematic negation of the topia on the way to utopia. Topia is a stabile combination of state, economics, school, art, and so on, a combination of all the spheres of commonality. However, this gradual

ically separated life from faith and substituted organized violence for spirit' (142). This era is marked by an absence, a lack of spirit, but it does not disappear entirely, but it appears sometimes in some individuals. The revolution in which we live has to bring together a new common spirit. Since that time there has been a long revolution regarded as a struggle for the reestablishment of Geist as principle of human life.

47 Ibidem, 111.

48 Ibidem, 121.

49 Ibidem.

50 On Landauer's concept of revolution as Zwischenzeit, cf. Norbert Altenhofer, "Tradition als Revolution. Gustav Landauer 'geworden-werdendes' Judentum," in Jews and Germans from 1860 to 1933: The problematic Symbiosis, ed. David Bronsen (Heidelberg: Carl Winter Universitätsverlag, 1979): 183. 
stability does not last for long. The changes are caused by utopia. ${ }^{51}$ Though it may appear dead, it is always a hidden force in history that resurrects whenever a topia reaches its limits. Therefore:

Revolution is always alive, even during the time of relatively stable utopias. It stays alive underground. It is always old and new. While it is underground, it creates a complex unity of memories, emotions and desires. This unity will then turn into a revolution that is not merely a boundary (or a spate of time), but a principle transcending all eras (topias). ${ }^{52}$

As stated by Landauer, anarchy is 'the expression for the liberation of man from the idols of the state, the church and capital, ${ }^{53}$ whereas scepticism as a systematic negation of every positive truth is the necessary strategy for anarchy. This negation is the heart of his (anti)political theory, particularly so in his famous conception of revolution. Revolution needs a negation of the topia on the way to utopia and this power of negation is the political translation of the act of doubting of all truths: 'Truth is, however, a completely negative word, it is the negation in itself, and therefore it is indeed the subject and aim of all science, whose long-lasting results are always of a negative nature. ${ }^{54}$ Scepticism and revolution have this need of negation in common which becomes a positive result, a creation that results from criticism.

In his conception of history Landauer challenged the very heart of the GermanHegelian conception of history as a self-realisation of the spirit, in a sceptical manner. He refuses any form of theorisation of history as a discipline and a Darwinian account of progress seen as inexorable and dogmatic historical tendencies. According to Landauer, a dogmatic idea of history-such as Marxism-impedes revolution. As scepticism engenders political action, dogmatism in contradistinction is an obstacle to change. His accusations against Marxism are at various levels. First of all, its view of a utopian project based on a scientific or rather a Darwinian idea of history, forwarding a mechanistic and deterministic view of history as self-driven progress,

51 It is fair to say that Landauer's interpretation of utopia is one of the most debated elements of his thought. Buber celebrated his friend in Paths to Utopia and, more broadly, Landauer has been defined as a thinker of contemporary utopia. In Revolution utopia plays a crucial role in his philosophy of history, however utopia should not be interpreted as a classic understanding of the term as a dream of a perfect society or as a rational political project. According to Landauer, utopia is the driving force of history seen as an alternation between topia and utopia, stabilisation and change. In the Revolution, Landauer deals with modern utopias, for instance Thomas More's work. Even if modern utopia was a rebellion and critique, it concerned a surrogate form of communality, namely the state. Furthermore, when Landauer speaks of Campanella's City of the Sun, he states: 'In Campanella's utopian system, the state has taken control of everything: love, family, property, education, religion. Campanella foresees the absolute democratic state, the state that knows neither society nor societies; the state that we call social democratic;' see Landauer, Revolution, 162. Also, in his Aufruf, Landauer clearly states that he does not offer any depiction of a utopian ideal.

52 Landauer, Revolution, 116.

53 Landauer, "Ethische Kultur," (March 7, 1896), reported by Lunn, Prophet of Community, 200.

54 Landauer, Skepsis und Mystik, 83. 
postulating that capitalism will inevitably collapse and the communism will be inevitable. This optimistic and dogmatic trust in inevitable collapse is at the root of Marxist determinism that impedes the action, whereas Landauer's writings place a strong emphasis on the voluntary aspect and a call to action.

Landauer reads the Marxist conception of history as a necessary development; ${ }^{55}$ it is a 'spiritless conception of history ${ }^{56}$ determined by providence. Landauer criticised the Marxist injunction of waiting for the 'supposed right moment,' which has

postponed this goal further and further and pushed it into blurred darkness; trust in progress and development was the name of regression and this 'development' adapted the external and internal conditions more and more to degradation and made the great change ever more remote. $^{57}$

Since revolution paves the way for something yet to come, rather than waiting for divine intervention, Landauer transposed the axis of hope to human Tat ('action') and human communities. This passage needs a sceptical attitude towards politics and institutions in order to create a different bond between individuals. He always emphasised the idea of beginning and underlined the need for action and the urgency of society's radical change, not to be postponed into a distant future, but to take place now.

Revolution can happen at any time and open the gate for the spirit. This idea was stressed by Landauer in a fascinating speech he gave as member of the work councils in Munich during the revolution: 'So anyone can help the revolution, anyone can heartily join it through any door, which is mostly already opened. ${ }^{58}$ The possibility of an overturning is possible anytime, hence there is a catastrophic-in the sense of the Greek word 'katastrophe' which means 'overturn'-conception of history in

55 Cf. Landauer, For Socialism, 60-63. Landauer refused to consider the proletarian as the predestined and privileged revolutionary agent. In his vision, it is not a matter of class, or perhaps more precisely a matter of historically favoured social groups, for the radical transformation required the development of cooperation among all working members. Furthermore, the Marxist definition of the proletariat is given only as an economic factor not taking into account spiritual poverty, while the real change starts from a spiritual one. In the place of a dictatorship of the proletariat Landauer called for a democracy of the entire working community. Moreover, Landauer also saw a connection between Marxism and technology, which he asserted to be responsible for the process of depersonalisation and dehumanisation of relationships. Landauer's aversion to technology has to be understood as aligned to his idea of spirit as authentic bond between man and man, man and nature, man and history. Capitalism, the modern state and technology are all part of the same constellation. 56 Ibidem, 61.

57 Ibidem, 109.

58 Gustav Landauer, “Zur Frage der Deutschen Verfassung," in Gustav Landauer und die Revolutionszeit, ed. Linse, 58. This passage recalls Benjamin's narrow gate through which the Messiah could enter in his "Theses on the Philosophy of History;" see Walter Benjamin, "On the Concept of History," in idem, Selected Writings, vol. 4, eds. Howard Eiland and Michael W. Jennings, trans. Edmund Jephcott et alii (Cambridge: Harvard University Press, 2003): 389-400. 
Landauer's thought. There is a tension between salvation and destruction at the very heart of his concept of revolution..$^{59}$ Against a progressive and evolutionist conception of history, Landauer formulated a different conception that we can define as an open and anti-dogmatic idea of history in which the messianic overturn can happen any time.

The third and last aspect of Landauer's anarchic conception of time deals with another account of revolution; in fact, at the end of his For Socialism, revolution is conceived as a permanent interruption of the order. In this essay Landauer quotes a passage from Leviticus $(25: 8-24)$ to emphasises the necessity of a revolution as a permanent interruption-Durchbruch-in order to redeem the whole of history. He interpreted this interruption on the basis of the Mosaic law, when the day of equalisation will come and 'every man is to regain what belongs to him.' This theological assumption gives more spiritual emphasis to Landauer's arguments:

[T] he voice of the spirit is the trumpet that will sound again and again and again, as long as men are together. Injustice will always seek to perpetuate itself, and always as long as men are truly alive, revolt against it will break out. Revolt as constitution; transformation and revolution as a rule established once and for all; order through the spirit as intention; that was the great and sacred heart of the Mosaic social order. We need that once again: new regulations and spiritual upheaval, which will not make things and commandments permanently rigid, but which will proclaim its own permanence. The revolution must become an element of our social order, it must become the basic rule of our constitution. ${ }^{60}$

According to Landauer, revolution must be a part of a social order, as the basis of the constitution and the permanent work of the spirit. This interruption is a messianic interval, but it could be compared to a sceptical epoché, a suspension of the rhythm of the time and an overturning of authorities. Since revolution is a negation but also an interruption of authority and of power, it could be defined as the sceptical heart of community.

In contrast with a Marxist tradition positing revolution needs a 'right moment' to happen, Landauer place it as Grundregel-basic rule-of our constitution. In a wonderful mosaic he puts together the subversive features of Judaism and the socialisticanarchistic tradition, as well as the restorative and utopian elements. ${ }^{61}$ Even though the relationship between Landauer and Judaism is controversial, ${ }^{62}$ I think that Lan-

59 At the outset of the Revolution, there is a passage from Maximus Tyrus: 'Here, now, you will see the road of passion, which you call destruction, because you make your judgment based on those who have already passed away on it-which I, however, call "salvation", basing myself on the order of those yet to come;' see Landauer, Revolution, 176.

60 Landauer, For Socialism, 130.

61 On the connection between anarchism and Jewish tradition, cf. Martin Buber, Königtum Gottes (Heidelberg: Schneider, 1956); Amedeo Bertolo, ed., L'anarchico e l'ebreo. Storia di un incontro (Milan: Eleuthera, 2001).

62 This is also one of the most discussed topics in secondary literature. For instance, according to Linse and Link-Salinger, the Jewish element is only one factor alongside the socialist and romantic 
dauer as a German Jew, who conceived his identity as a complexity, ${ }^{63}$ anticipated the feeling of the bifurcated soul of a whole generation of thinkers of the last century. ${ }^{64}$ Thanks to his association with Martin Buber, Landauer became familiar with Jewish tradition and Jewish questions. Undoubtedly in the last years of his life, he was enthusiastic for Jewish national renaissance. After his death, Buber spoke of Landauer as the 'secret leader' of the Zionist movement and tried to translate his legacy from Germany to Israel. ${ }^{65}$

traditions in Landauer's thought; but Lunn points out that Jewish heritage played a pivotal role in Landauer's idea of redemption and the binding power of spirit. Cf. Link-Salinger, Gustav Landauer: Philosopher of Utopia, 74-76; Lunn, Prophet of community, 247. Hanna Delf, "'Prediger in der Wüste sein.' Gustav Landauer im Weltkrieg," in Gustav Landauer, Werksausgabe. Gustav Landauer. Dichter, Ketzer, Außenseiter, vol. 3, ed. Hanna Delf (Berlin: Akademie, 1997), XXIII-LI; Siegbert Wolf, "Einleitung," in Gustav Landauer, Ausgewählte Schriften. Philosophie und Judentum, vol. 5., ed. Siegbert Wolf (Lich/Hessen: Edition AV, 2012): 9-85.

63 In one of his most important writings on Judaism-Sind das Ketzergedanken?-published in the volume Vom Judentum in 1913 and edited by the Zionist organisation in Prague Bar Kochba, Landauer wrote: 'I am, the Jew, a German. The expressions "German Jew or Russian Jew" are as obtuse as would be the terms "Jewish German" or "Jewish Russian". The relation is not one of dependency and cannot be described by means of an adjective modifying a noun. I accept my fate as it is. My Germanism and my Jewishness do each other no harm but much good. As two brothers, a first-born and a Benjamin, are loved by mother-not in the same way but with equal intensity-and as these two brothers live in harmony with each other whenever their paths proceed in common and also whenever each goes his own way alone, even so do I experience this strange and intimate unity in duality as something precious;' translated by Lunn, Prophet of community, 270. The special calling for humanity that characterised Judaism is that all Jews bear 'their neighbours in their own breasts;' see ibidem, 217. The Jewish Volk is free from the trap of the state which is also a threat to the integrity of Jewish identity. In his short lecture entitled "Judaism and Socialism" given to the Zionistische Ortsgruppe West Berlin on February 12, 1912, Landauer admitted the possibility of Jewish settlements but at the same time he supported the messianic feeling of Galut among the nations as chance of redemption for the humankind: 'The Galut, exile as an inner disposition of isolation and longing, will be that utmost calling that bonds them to Judaism and Socialism;' translated by Paul Mendes-Flohr, "Introduction," in Gustav Landauer: Anarchist and Jew, 1-2. The redemptive mission and the commitment of Jewish people of increasing brotherhood and justice is akin to socialism. His provocative idea was that Galut linked Judaism to Socialism, since Jewish people were particularly qualified for the task of helping to build socialist communities.

64 See Paul Mendes-Flohr, German Jews: A Dual Identity (New Haven and London: Yale University Press, 1999), 1-2.

65 See Martin Buber, "Der heimliche Führer," in Gustav Landauer Gedenkheft, in Die Arbeit (1920): 35: 'Gustav Landauer was an awakener for us; he has transformed our lives, and he has given our Zionism-which he never mentioned by name-a new meaning, a new intensity, a new direction;' see also Martin Buber, "Landauer und die Revolution," Masken: Halbmonatsschrift des Düsseldorfer Schauspielhauses 14.18-19 (1919): 291; Bar Kochba, ed., Vom Judentum (Leipzig: Kurt Wolff, 1913). 


\section{Scepticism as Anti-Political Form of Life}

Landauer's idea of revolution deals with the power of negation, with his conception of history and with a politicisation of time to provide a regeneration of humankind. As noted above, he proposed a qualitative conception of historical time: the revolution is a meta-historical element that could happen in a sudden eruption and historical metamorphosis of an abrupt moment, Durchbruch. At the same time, revolution is a renewal of humankind and a process taking place in the individual's interiority. In his preface to the second edition of the Aufruf Landauer talks of the transformative feature of the revolution, stating that in the revolution 'the incredible miracle is brought into the realm of possibility. ${ }^{, 66}$ This aesthetic and ethic renovation of the spirit involves joy, love, transcendence, religion. ${ }^{67}$ The conversion of the greatest difficulty and necessity into the highest virtue, of the crisis into socialism is the hardest task of revolution.

Thence, revolution is not just a political event, but rather it is a metànoia-a conversion, an exercise of becoming and an interior transformation in order to create new relationships between men. I think that this conception of revolution as conversion is also the key to understanding his initial participation in the Bavarian Soviet Republic; in fact, he enthusiastically participated in this revolution as a spiritual guide, following Eisner's suggestion to join it for a 'transformation of the souls' ('Umbildung der Seele'). ${ }^{68}$

66 Landauer, For Socialism, 21.

67 In the preface of his For Socialism, Landauer speaks of true socialism and social change as a religion of action and love. His religious and prophetical vein is also the element that his friends-after his death-will take to save his memory and celebrate Landauer as a martyr of revolution; see, ibidem, 26: "May the revolution bring rebirth. May, since we need nothing so much as new, uncorrupted men rising up out of the unknown darkness and depths, may these renewers, purifiers, saviours not be lacking to our nation. Long live the revolution, and may it grow and rise to new levels in hard, wonderful years. May the nations be imbued with the new, creative spirit out of their task, out of the new conditions, out of the primeval, eternal and unconditional depths, the new spirit that really does create new conditions. May the revolution produce religion, a religion of action, life, love, that makes men happy, redeems them and overcomes impossible situations.' Furthermore, at the end of his Revolution, he underlines this idea of joy and revolution as a kind of divine or mystic ecstasy; see Landauer, Revolution, 171-172: 'The joy of revolution is not only a reaction against the former oppression. It lies in the euphoria that comes with a rich, intense, eventful life. What is essential for this joy is that humans no longer feel lonely that they experience unity, connectedness, and collective strength.'

68 Gustav Landauer, Sein Lebensgang in Briefen, vol. 2, 296 note 1: 'Kurt Eisner hatte am 14. November an Landauer geschrieben: "Kommen Sie, sobald es Ihre Gesundheit erlaubt. Was ich von Ihnen möchte, ist, daß Sie durch rednerische Betätigung an der Umbildung der Seelen mitarbeiten.”' In the Munich Revolution, Landauer saw a prophetical realisation of the spirit. He was deeply convinced of a spirituality transforming of revolution. It is worth noting that in his speeches and writings during the Räterepublik, Landauer spoke or wrote as a spiritual guide or as a prophet of the spirit that is yet to come. 
According to Landauer, anarchy is based on a deep scepticism towards political dogma, institutions and authority. It is in no way an abstract model or doctrine, but an ethic and spiritual form of life whose aim is the Bildung of a new man ('der werdende Mensch') and a new community based on an authentic social justice. In Landauer's view the libertarian approach is radically rethought in a holistic harmony in which there is a kind of anarchic poiesis.

One of the most innovative aspects in his thought is the distinction between an idea of politics as artificial device of power-also to found in Marxism-and an antipolitical approach. In his Anarchic Thoughts about Anarchism Landauer writes: 'Anarchy is not a matter of the future; it is a matter of the present. It is not a matter of making demands; it is a matter of how one lives. ${ }^{69}$ Anarchy is seen in psychological terms and is described as a radical transformation of human being. This is also the reason why his revolutionary activity was a kind of Lebensform, as it concerns all dimensions of life.

Landauer's Anti-Politik arises from his criticism of modern political thought. He barely distinguished his idea of socialism from politics in general: 'socialism is a cultural movement, a struggle for beauty, greatness, abundance of the peoples. ${ }^{70}$ Whereas the politician is interested only in a partial aspect of the human life, socialist thinks holistically: 'whether he is a thinker or a poet, a fighter or a prophet: the true socialist will always have a vital element of the universal in him. ${ }^{71}$ Whereas socialism concerns all aspects of human life, politics is surrogate and a device which deals with but partial aspects. Politics is a technique related to state, representation and institution, while anti-politics could be interpreted as a sceptical attitude against power; in fact, as it is a Gegenmacht ('counter power') that refuses to become power, it could be interpreted as a sceptical stand which avoids dogmatic conclusion and ruling institutions.

Anti-politics is a strategy to discard doctrine or assumptions from the flux of life which is impossible to define in scientific terms. In the work and in the biography of Landauer one can see a lively exemplum of anarchy as a sceptical refusal of political dogmatism. He uses sceptical argumentations in his philosophical political thought and in his anti-political praxis as well. Scepticism has many different features in his thought: it is a radical critique towards state, dogmatism and progress; the way to follow in order to discover a lively idea of community based on a particular idea of time and history; a critique towards idols and authorities, and a living praxis which is an ongoing challenge to dogmatic power.

In a compelling puzzle of many elements his thought provides both warnings and the pathway for a radical challenge to politics. His immolation as a martyr of community symbolised his radical attempt to connect an open revolution to a scep-

69 Gustav Landauer, “Anarchic Thoughts about Anarchism,” in idem, Revolutions and Other Writings, 87.

70 Landauer, For Socialism, 64.

71 Ibidem, 45. 
tical form of life; on the other hand, however, his death shows the controversial consequences of an anti-political attitude that later became a tragic constant in the history of the last century. Landauer was a medieval mystic, an old-fashioned socialistanarchist, a linguistic sceptic, and a tormented spirit from the beginning of the twentieth century. In this regard, he was the first thinker who combined a thinking of community with the breakdown of certainty; as a result, he demonstrated the extreme consequences of a sceptical definition of politics and an anarchic conception of time. I believe this to be the very heart of his legacy through which it could be possible-even to this day-to develop a more philosophical thinking of community as a bond between human beings, beyond dogmatic assumptions and technical accounts of politics. 